\title{
Wound Care Management
}

National Cancer Institute

\section{Source}

National Cancer Institute. Wound Care Management. NCI Thesaurus. Code C116681.

Any action taken to for the purpose of helping a wound heal; this generally involves keeping the affected area clean and dry, and may involve periodic debridement of any necrotic tissue, or washing of the area with antibacterial solution. 